Шедяков В. Е., д.с.н., к.э.н., доцент независимый исследователь 2. Киев, Украина

DOI: https://doi.org/10.30525/978-9934-26-028-5-46

\title{
ПЕРЕХОДНЫЙ ПЕРИОД: \\ РАДИКАЛЬНАЯ ГУМАНИЗАЦИЯ ОБЩЕСТВЕННЫХ ОТНОШЕНИЙ - ВАЖНЕЙШИЙ ФАКТОР ГАРМОНИЗАЦИИ ПРОЦЕССОВ ИНДИВИДУАЛИЗАЦИИ И СОЦИАЛИЗАЦИИ / АККУЛЬТУРАЦИИ
}

Происходящее взламывание вызревшими новыми общественными отношениями прежних социально-политических форм обостряет вопрос об употреблении Интернета: цифровизация оказывается инструментом преимущественно Добра или Зла? Пандемия же не только отсрочила решительное разрешение ряда глобальных проблем, но и обострила их, а требуемая дистанционность выверяет общественные и индивидуальные смыслы и усиливает роль коммуникаций [1-5]. И радикальная гуманизация общественных отношений (прежде всего, системообразующих для общественной целостности отношений труда, собственности и власти / управления) - магистральное направление социальной адаптации к требованиям новой эпохи с её мерой соотношения индивидуализации и социализации.

Рефлексивное сознание формируется динамикой социального и индивидуального развития, востребуя того и другого. При культуре модерна, свойственной индустриальному обществу, доминирование внеэкономических форм принуждения сменяется экономическими. Оторвавшись от животного и родового начала, человек начинает ощущать трансцендентность своего одино- 
чества, своей конечности. Социальный аспект отчуждения различие в уровнях культуры и богатства, освоенных всем обществом и его отдельными социальными группами, профессиональными, национальными, партийно-идеологическими корпорациями. Личностный аспект - утрата самотождественности: индивид перестает соответствовать собственным и родовым человеческим качествам.

Сменивший традиционную организацию модерн был ознаменован инновационностью поведения, машинной организацией производства товаров, обезличенностью социальных связей, приоритетом материального над духовным, объективного над субъективным, организации над органичностью. Модерн оказался связанным с культурой агрессии, монолога, насильственной социализации и стандартизации. Он идентифицировался с позитивностью, рациональностью, сциентизмом, утилитаризмом, монотонностью, упованиями на линейный прогресс по единому канону, идеологией построения оптимальной социальной организации на базе рацио. Т.о. культура модерна, возникшая для обслуживания индустриального социума, стала характерна странам с высоким уровнем конвейеризации массового товарного производства на конкурентные рынки, устойчивым экономическим ростом и солидным валовым и подушевым доходом, верой в рациональное знание как основу прогресса, рациональной бюрократией, профессиональной мобильностью рабочей силы, стратификацией и дифференциацией населения, большим удельным весом и общественной роли «среднего класса». Со временем западная модель сочетания индивидуализации и социализации / аккультурации исчерпала свой созидательный порыв, а освобождение человека в её контексте стало лишь высвобождением животных инстинктов. Порождённая ею нескончаемая череда кризисов не имеет в её рамках продуктивного разрешения для ойкумены, а взыскует кардинальных изменений на основе одушевления, гуманизации и, тем самым, гармонизации общественных отношений. Одновременно 
развитие биотехнологий и робототехнических систем создают предпосылки для таких трансформаций [6-9].

Переходный период к новой общественной практикотеоретической парадигме предполагает высвобождение в сотворчестве сугубо индивидуального комплекса одарённости как решающего фактора дальнейшего общественного развития. Период сконцентрированных преобразований - переход отнюдь не к какому-либо одному определённому для всех культурноцивилизационных миров образцу образа жизни, общественного устройства, политического режима и т.д., а именно к новой общественной парадигме (в частности, ориентированной как раз, напротив, на рост многообразия). Полиструктура мирохозяйственных связей как целостность, основанная на выработанных и взаимоприемлемых нормативах отношений, а вовсе не блок из идентичных атомов-элементов приобретает вид формируемой действительности. Естественно, приметы новой общественной практико-теоретической парадигмы достаточно серьёзны и несут последствия, которые могут кардинально разниться в зависимости от того, кто выступает субъектом перемен, каковы его интересы и осознание их. В частности, весомым параметром общественной жизни становится противоборство представителей не только уходящей и нарождающихся моделей, но и их различных вариантов. Так, приходится осознавать, что движение к заведомой плюральности общественных подходов на практике означает, в частности, необходимость мириться с заведомой разнокачественностью политических режимов, хозяйственных укладов, стилей жизни и т.п. С одной стороны, для отстаивания своей суверенности и самобытности культурно-цивилизационный мир должен обладать достаточно весомым потенциалом (в т.ч. демографическим). С другой стороны, для наращивания своих возможностей вовсе нет необходимости следовать внешним, оказавшимися где-то и на каком-то этапе успешными, канонам [10-12]. Напротив, дифференциация, опора на свою идентичность, осознание своеобразия может открыть для культурно-цивилизационного мира решающие конкурентные преимущества. 


\section{Литература:}

1. Букреев В.И. Расчеловечивание человека в мировой истории: истоки и глобальные последствия: психоантропология. Москва : Флинта: Наука, 2011. $405 \mathrm{c}$.

2. Gamble A. Crisis Without End? The Unravelling of Western Prosperity. UK : Palgrave Macmillan, 2014. $240 \mathrm{p}$.

3. Ростовцева М.В. Философские аспекты социальной адаптации в процессе становления и развития личности. Дисс. ... доктора философ. наук. Красноярск, 2017. 304 c.

4. Шедяков В.Е. Взаимосвязи индивидуализации и социализации сквозь призму очеловечивания условий общественной жизнедеятельности. Сучасні політичні прочеси: глобальний та національний виміри: Матер. Міжнар. наук.практ. інтернет-конф. НУ «ОЮА». Одеса, 28 вересня 2018. С. 42-47. [Електронний ресурс]. URL: http://dspace.onua.edu.ua/handle/11300/10828.

5. Shedyakov V. Pandemic and change of public paradigm: political and economic aspects of the transition. Pandemic Economic Crisis: Changes and New Challenges to Society / scient. ed. by M. Bezpartochnyi. Sofia : St. Grigorii Bogoslov, 2020. P. 48-60. DOI https://doi.org/10.5281/zenodo.4396028.

6. Кропоткин П.А. Взаимопомощь как фактор эволюции. Москва : Самообразование, 2007. $240 \mathrm{c}$.

7. Шедяков В.Е. Творче засвоєння світу - елемент соціалізації / акультурації. Modern methods, innovations and operational experience in the field of social sciences: Proceed. of Intern. research \& practice conf. Maria Curie-Sklodowska University, Lublin Science and Technology Park S.A. Lublin, Oct. 20-21, 2017. P. 154-156.

8. Шедяков В.Е. Трансформации общественные и наук об обществе. Ежемесячный научный журнал: по Матер. XIII Междунар. конф. «Развитие экономических и межотраслевых наук в XXI веке». Новосибирск : Научный институт глобальной и региональной экономики (НИГРЭ). 2015. № 6 (13). C. 68-71.

9. Шедяков В.Е. Гармонизация индивидуального и социального в становлении общества знания. European vector of contemporary psychology, pedagogy and social sciences: the experience of Ukraine and the Republic of Poland I ed. board: M. Kiedrowska, A. Erechemla, T. Branecki. Sandomierz : Baltija Publishing, 2018. Vol. 3. P. 446-470.

10. Fallaci O. The Rage and the Pride. Universe Publishing, 2002. 187 p.

11. Buchanan P.J. The Death of the West. USA: St. Martin's Press, 2001. 320 p.

12. Шедяков В.Е. Власть и управление: адекватность условиям развития. Scientific Collection «InterConf». 2020. No 1 (37). Dec.: with the Proceed. of 1 Intern. Scient. \& Pract. Conf. «Recent Scientific Investigation» (Oslo, Dec. 6-8, 2020). P. 457-465. 